Available online at website : http://journal.uinjkt.ac.id/index.php/dialektika

DIALEKTIKA: jurnal bahasa, sastra, dan pendidikan bahasa dan sastra Indonesia, 3(1), 2016, 52-66

\title{
REPRESENTASI KEKERASAN SIMBOLIK TERHADAP PEREMPUAN BETAWI DALAM NOVEL KRONIK BETAWI KARYA RATIH KUMALA
}

\author{
Nina Farlina \\ UIN Syarif Hidayatullah Jakarta, Indonesia \\ E-mail: nina.farlina@uinjkt.ac.id
}

\begin{abstract}
This article is an analysis of the representation on the symbolic violence by Pierre Bourdieu against the Betawi women in Kronik Betawi Novel's Ratih Kumala. This methode uses the qualitative methode from literature studies to analize the symbolic violence against the Betawi women in this novel. The symbolic violence in this novel occurs when the traditional values and religion that tend to patriachal system. It can infleuence the Betawi women in determining the role and the position of Betawi women in everyday life, like Juleha character in this novel. The Betawi women can not contribute freely in public area. However, the Betawi women can also contribute in the reconstruction of Betawi women identity in public area with the cultural values and religion like Edah character. Indeed, in this novel, there is the construction of identity Betawi women and the important role of Betawi women in development of country.
\end{abstract}

Keywords: symbolic violence; Betawi women; patriarchal; Kronik Betawi

\begin{abstract}
Abstrak: Artikel ini membahas tentang representasi kekerasan simbolik oleh Pierre Bourdieu terhadap kaum perempuan Betawi dalam novel Kronik Betawi karya Ratih Kumala. Metode yang digunakan adalah pendekatan kualitatif yang diambil dari kajian pustaka mengenai kekerasan simbolik terhadap kaum perempuan Betawi dalam novel Kronik Betawi. Kekerasan simbolik dalam novel ini terjadi karena adanya nilai-nilai tradisional Betawi dan religi yang cenderung patriaki yang memberikan pengaruh dalam menentukan peran dan posisi kaum perempuan Betawi dalam kehidupan sehari-hari yang bersifat termarginalisasi, subordinasi, sebagaimana karakter Juleha dalam novel tersebut. Sehingga kaum perempuan Betawi tidak dapat berkontribusi di ranah publik dengan leluasa karena adanya nilai-nilai adat dan religi. Namun, kaum perempuan Betawi dapat juga memberikan kontribusinya dalam proses rekontruksi identitas perempuan Betawi dalam nilai-nilai budaya dan agama di ranah publik sebagaimana yang diperankan Edah meskipun marginalisasi juga terjadi. Hal tersebut merupakan bentuk kontruksi identitas kaum perempuan Betawi sehingga kekerasan simbolik dapat terhindarkan. Peran perempuan Betawi dapat diperhitungkan dalam kemajuan bangsa dan negara.
\end{abstract}

Kata Kunci: kekerasan simbolik; perempuan betawi; patriarki; Kronik Betawi

Permalink/DOI: http://dx.doi.org/10.15408/dialektika.v3i1.4181 


\section{Pendahuluan}

Kesetaraan dan keadilan gender sudah menjadi isu yang sangat penting dan sudah menjadi komitmen bangsa-bangsa di dunia termasuk Indonesia. Hal tersebut merupakan bentuk penolakan terhadap kekerasan terhadap perempuan seperti kekerasan seksual, pelecehan, dan marginalisasi kaum perempuan dalam kehidupan sehari-hari. Kemunculan isu tersebut merupakan salah satu bentuk kesadaran akan kesetaraan dan keadilan gender di Indonesia. Gender menurut Butler merupakan pembagian peran antara laki-laki dan perempuan yang sudah dikonstruksikan dan dibentuk pada masa waktu tertentu pula, sehingga gender itu bersifat dinamis. ${ }^{1}$

Sedangkan konsep gender sendiri berbeda dengan konsep jenis kelamin secara biologis (seks). Fakih mengemukakan bahwa pengertian seks itu sendiri merupakan pensifatan atau pembagian dua jenis kelamin (perempuan dan lakilaki) secara biologis, sedangkan gender merupakan sifat yang melekat pada kaum laki-laki ataupun perempuan yang dikonstruksi oleh sosial ataupun budaya. ${ }^{2}$ Mengacu kepada pengertian gender tersebut, ketimpangan dan relasi gender muncul karena adanya aturan, tradisi dan hubungan timbal balik yang menentukan batas antara feminitas dan maskulinitas sebagaimana yang diungkapkan Azyumardi Azra dalam buku Pengantar Kajian Gender. ${ }^{3} \mathrm{Hal}$ tersebut berdampak pada pembagian peran dan kekuasaan antara laki-laki dan perempuan dalam kehidupan sosial, seperti berkembangnya mitos kaum lakilaki lebih cerdas, bertanggung jawab, dan kuat. Mitos tersebut mempengaruhi perilaku masyarakat seperti orang tua dalam mendidik anak-anaknya yang lebih mengutamakan menyekolahkan anak laki-laki dibandingkan perempuan, perundang-undangan juga masih berpihak pada salah satu jenis kelamin dengan kata lain masih belum mencerminkan kesetaraan gender seperti pasal 31 (3) dan pasal 34 (1) dan (3) UU Perkawinan yang masih ambivalen dan bias gender dalam menentukan kedudukan dan peran perempuan dan laki-laki dalam keluarga. Selain itu, penafsiran ajaran agama yang kurang komprehensif atau cenderung tekstual dibandingkan dengan kajian kontekstual seperti penafsiran asal kejadian manusia dalam QS. 4:1, yaitu:

${ }^{1}$ Judith Butler, Gender Trouble, (New York : Routledge, 1990), h. 90

${ }^{2}$ Fakih, Pengantar Kajian Gender, (Jakarta: UIN Syarif Hidayatullah, 1996), h. 54-55.

${ }^{3}$ Pusat Studi Wanita, Pengantar Kajian Gender, (Jakarta: UIN Jakarta, 2003), h. vii. 


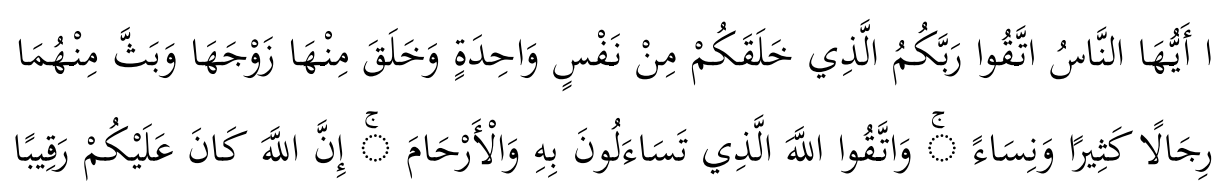

"Hai sekalian manusia, bertakwalah kepada Tuhanmu yang telah menciptakan kami dari "nafs" yang satu (sama) dan darinya Allah menciptakan kami dari keduanya, Allah memperkembangbiakkan laki-laki dan perempuan yang banyak" (Q.S. An Nisa: 1).

Penafsiran kata nafs pada ayat tersebut adalah Adam (laki-laki) sehingga Hawa (perempuan) merupakan bagian dari Adam (laki-laki). Penafsiran tersebut berbeda dengan kalangan mufassir modern yang memahami nafs dalam pengertian jenis, yaitu laki-laki dan perempuan diciptakan dari jenis yang sama dan terdapat implikasi yang berbeda dimana perempuan lebih rendah daripada laki-laki dan kesejajaran antara laki-laki dan perempuan. ${ }^{4}$ Dari contoh tersebut, diperlukan reorientasi pemahaman terhadap ayat dan hadits sebagaimana yang diungkapkan Fadilah Suralaga untuk menempatkan kedudukan dan peranan perempuan sesuai dengan proporsi yang benar. Hal tersebut yang menyebabkan ketidaksetaraan gender.

Penelitian ini menganalisis kehidupan kaum perempuan Betawi dalam kegiatan keseharian mereka yang dikemas dalam novel Ratih Kumala yang berjudul Kronik Betawi. Perempuan Betawi dalam novel Kronik Betawi memberikan kontribusi dalam proses representasi identitas dan karakter perempuan Betawi sebagai masyarakat asli Jakarta yang mengalami modernisasi. Sebagaimana yang diungkapkan Elfira dalam penelitiannya bahwa terdapat nilai-nilai tradisional dan religi yang cenderung patriarki yang telah membatasi gerak-gerik kegiatan perempuan Betawi dalam kesehariannya. Sehingga perempuan Betawi tidak mendapatkan kebebasan dalam kehidupan yang mengakibatkan kekerasan dalam lingkungan domestik maupun di lingkungan masyarakat. Kekerasan terhadap kaum perempuan bukan hanya berupa kekerasan fisik, namun kekerasan terhadap kaum perempuan dalam novel tersebut merupakan refleksi dari banyaknya ketidakadilan gender di masyarakat yang menempatkan perempuan sebagai kelompok marjinal. ${ }^{6}$ Seperti halnya perempuan tinggal di rumah untuk mengurus anak-anak dan rumah tangga

\footnotetext{
${ }^{4}$ Pusat Studi Wanita, Pengantar Kajian Gender ....., h. viii.

${ }^{5}$ Pusat Studi Wanita, Pengantar Kajian Gender ....., h. viii.

${ }^{6}$ Mirna Elfira, Aktifitas Kaum Perempuan Betawi Dalam Masyarakat Multikultural: Antara Tradisi dan Modernisasi, (Depok: Universitas Indonesia, 2012), h. 33-34.
} 
yang diterima sebagai sesuatu yang sudah semestinya dan wajar. Sebagaimana yang diungkapkan Haryatmoko bahwa representasi Tuhan mengacu pada jenis kelamin laki-laki yang tidak perlu dipertanyakan lagi di mana perempuan diciptakan dari tulang rusuk laki-laki. Dengan konsepsi anthropologis, sosiologis, dan teologis, jika terjadi hubungan laki-laki dan perempuan yang merugikan pihak perempuan memiliki implikasi yang perlu dianalisis, yaitu kekerasan.

\section{Metode Penelitian}

Penelitian ini merupakan penelitian kualitatif yang berdasarkan pada kajian kepustakaan dari beberapa sumber kajian. Sumber primer pada kajian kepustakaan ini adalah novel Kronik Betawi karya Ratih Kumala yang terbit pada tahun 2009. Ratih Kumala adalah seorang penulis novel Kronik Betawi keempat yang bercerita tentang Jakarta dan anak daerahnya yang tergusur dan tergeser oleh arus modernisasi. Novel-novelnya antara lain: Tabula Rasa (2004), Genesis (2005), Larutan Senja (2006), Kronik Betawi (2009), Gadis Kretek (2012) dan mendapatkan penghargaan sebagai Short-list Khatulistiwa Literary Award 2012. ${ }^{8}$ Novel tersebut berasal dari cerita bersambung Harian Republika pada bulan Agustus-Desember 2008 dan ide cerita tersebut berasal dari Nugroho Suksmanto.' Kronik Betawi merupakan representasi dari kehidupan masyarakat Betawi yang menghadapi permasalahan seperti modernisasi terutama dari para pendatang, pembangunan yang semakin padat dan tak beraturan sehingga menghilangkan asal-usul serta sejarah tempat-tempat tersebut. Dengan gaya khas Betawi seperti menyindir, dan ceplas ceplos, Ratih Kumala ingin memunculkan memori nilai-nilai kehidupan budaya Betawi yang setiap tokohnya memikul persoalan sebagai orang Betawi pada masa sebelum tahun 1998. Novel tersebut diwakili oleh tiga bersaudara sebagai karakter utama, yaitu Haji Jaelani, seorang pengusaha sapi perah yang mengalami penggusuran, padahal tanah tersebut merupakan warisan dari babehnya (bapaknya); Haji Jarkasi, seorang pemain lenong yang pernah berguru pada Haji Bokir yang pernah dilarang pemerintah untuk mengamen; dan Juleha, seorang istri yang dipoligami oleh suaminya karena belum memiliki keturunan. Definisi

\footnotetext{
${ }^{7}$ Haryatmoko, Habitus dan Kapital dalam Strategi Kekuasaan: Teori Strukturasi Pierre Bourdieu dengan Orientasi Budaya, (Depok: Universitas Indonesia, 2010), h. 14.

${ }^{8}$ Ratih Kumala, Diunduh dari, http://ratihkumala.com/blog/kronik-betawi-sebuah-novel-3-398.php, tanggal 7 Januari 2016, pukul 11:05.

${ }^{9}$ Ratih Kumala, Ratih Kumala, Kronik Betawi, (Jakarta: Gramedia Pustaka Utama,2009), h .ii.
} 
"Poligami" dalam Kamus Besar Bahasa Indonesia (KBBI) merupakan sistem perkawinan yang salah satu pihak memiliki atau mengawini beberapa lawan jenisnya dalam waktu yang bersamaan. ${ }^{10}$ Selain itu, dalam novel tersebut juga terdapat tokoh tambahan yaitu Edah (anak Haji Jarkasih) yang mendapatkan larangan menari oleh ibunya, Juned dan Japri (anak Haji Jaelani) yang tidak melanjutkan sekolah dan lebih memilih menjadi tukang ojek, sebaliknya Fauzan (anak dari istri kedua Haji Jaelani) yang lebih memilih untuk melanjutkan pendidikan S-2 di luar negeri dan mendapatkan beasiswa tersebut.

Dengan berbagai permasalahan yang terjadi pada karakter-karakter tersebut, penulis tertarik untuk meneliti representasi kaum perempuan Betawi yang diperankan oleh karakter Juleha dan Edah yang berasal dari dua generasi yang berbeda. Mereka memiliki permasalahan-permasalahan yang berbeda yang menyebabkan mereka mengalami kekerasan simbolik dalam kehidupannya, seperti yang dikemukakan Pierre Bourdieu.

\section{Landasan Teori}

Keprihatinan Bourdieu melandasi hasrat mendasar terhadap perubahan dan lingkungan sosial terutama dominasi maskulin yang sangat menyakitkan bagi kaum perempuan. Seperti halnya perempuan harus tinggal di rumah dan merawat anak, bahkan perempuan harus menanggung malu karena tidak dapat mengungkapkan nama laki-laki yang telah menghamilinya. Penguasaan dan wacana menjadikan dominasi laki-laki seakan-akan sebagai sesuatu yang alamiah dan bisa diterima. ${ }^{11}$

Ketika hubungan dominan-terdominasi tengah direproduksi, sebenarnya pada saat yang sama terjadi pula -dalam bahasa Bourdieu- "kekerasan simbolik" (symbolic violence) atau kekerasan yang tak kasat mata ${ }^{12}$, yaitu proses dimana si dominan merasa berhak menentukan makna dari suatu hal sebagai satu-satunya pandangan yang paling benar. Kekerasan semacam ini oleh perempuan yang menjadi terdominasi bahkan tidak terlihat atau tidak dirasakan sebagai kekerasan, namun sebagai sesuatu yang alamiah dan wajar. ${ }^{13}$ Oleh karena itu,

\footnotetext{
${ }^{10}$ Anonim, http:/ / kbbi.web.id/poligami, diunduh pada tanggal 7 Januari 2016.

${ }^{11}$ Haryatmoko. Habitus dan Kapital Dalam Strategi Kekuasaan: Teori Strukturasi Pierre Bourdieu dengan Orientasi B,.....h. 13.

${ }^{12}$ Pierre Bourdieu, La domination masculine, (Paris: Minuit, 1998), h. 7.

${ }^{13}$ Haryatmoko, Habitus dan Kapital dalam Strategi Kekuasaan: Teori Strukturasi Pierre Bourdieu dengan Orientasi Budaya ....., h. 13 .
} 
perempuan sebagai kelompok terdominasi cenderung mengidentifikasi diri mereka sebagai 'yang inferior' dengan cara mengadopsi pendapat laki-laki, mengamini aturan-aturan yang dibuat laki-laki, serta membangun citra diri seperti yang diinginkan laki-laki sebagai kelompok dominan. ${ }^{14}$ Dengan demikian, kekerasan simbolik bukanlah kekerasan yang dilakukan secara fisik.

Karena tidak diakui sebagai salah satu bentuk kekerasan, kekerasan simbolik paling efektif dipraktekkan dalam masyarakat -dalam terminologi Bourdieu- "doxic", dimana aturan-aturan kosmologi dan politik yang mapan tidak pernah dirasakan sebagai kesewenang-wenangan. ${ }^{15}$ Berkaitan dengan ini Bourdieu memperkenalkan konsep doxa -bahwa dalam masyarakat tradisional dan stabil sesuatu yang natural akan terbukti dengan sendirinya, orthodoxy usaha untuk mempertahankan doxa, dan heterodoxy -usaha untuk menantang doxa. ${ }^{16}$ Dalam masyarakat seperti ini, segala sesuatunya berjalan tanpa pernah dipertanyakan. Sementara etika kehormatan dijunjung tinggi, kebebasan berpendapat ditekan. Menurut Haryatmoko pada dasarnya kekerasan simbolis merupakan ketidaktahuan dan pengakuan dari yang ditindas. Dominasi ini terus berjalan karena adanya prinsip simbolis yang diketahui dan diterima baik oleh yang menguasai maupun yang dikuasai. ${ }^{17}$ Prinsip simbolis itu berupa bahasa, gaya hidup, cara berpikir, cara bertindak dan kepemilikan yang khas pada kelompok tertentu atas dasar ciri kebutuhan.

Selain itu, penulis juga menganalisa kekerasan simbolik yang direpresentasikan dalam novel Ratih Kumala "Kronik Betawi". Representasi dalam kajian budaya merupakan konsep kunci dalam penelitian budaya. Representasi menjadi hal yang penting dalam menghubungkan makna (arti) dan bahasa dengan budaya. Representasi berarti menyatakan sesuatu atau menggambarkan dunia yang penuh arti kepada orang lain. Stuart Hall mendefinisikan representasi sebagai bagian yang essensial dari proses makna dihasilkan atau diproduksi dan diubah antara anggota budaya tersebut. ${ }^{18}$

\footnotetext{
${ }^{14}$ Beate Krais, The Gender Relationship in Bourdieu's Sociology, dalam SubStance no. 93, 2000, h. 59; Swartz, David. Culture and Power: The Sociology of Pierre Bourdieu, (Chicago: University of Chicago Press, 1997), h. 103.

${ }^{15}$ Toril Moi, Apropriating Bourdieu: Feminist Theory and Pierre Bourdieu's Sociology of Culture, dalam Pierre Bourdieu, vol. IV, Derek Robin (ed), (London: Sage Publications Ltd, 2000), h. 322.

${ }^{16}$ Troil Moi, Apropriati.ng Bourdieu....., h. 322.

${ }^{17}$ Haryatmoko, Habitus dan Kapital dalam Strategi Kekuasaan: Teori Strukturasi Pierre Bourdieu dengan Orientasi Budaya....., h. 14.

${ }^{18}$ Stuart Hall, Cultural Identity and Diaspora dalam Representation: Cultural Representations and Signifying Practices, (London: Sage Publication Ltd, 1997), h. 51-52.
} 
Dalam sebuah representasi yang dikonstruksi bukan hanya makna saja tetapi juga identitas. Menurut Hall identitas adalah sebuah produksi yang berlangsung secara terus menerus dan tidak pernah selesai dan bahwa identitas "always constituted within, not outside, representation". 19 Oleh sebab itu, identitas memiliki hubungan yang erat dengan representasi. Representasi melibatkan "symbolic system" dalam bentuk bahasa dan citra visual akan menghasilkan makna tertentu. Makna tersebut dalam bentuk bahasa dan citra visual akan diasosiasikan dengan identitas tertentu. ${ }^{20}$ Dengan cara tersebut identitas diproduksi, dikonsumsi, dan diregulasi dalam kebudayaan melalui representasi. ${ }^{21}$ Kemudian konstruksi identitas melalui representasi tersebut akan terus berlangsung terus menerus dan tidak pernah selesai karena identitas bersifat non-essensialis. ${ }^{22}$

Dalam novel tersebut, identitas kaum perempuan Betawi dihasilkan dengan menghadirkan berbagai representasi mengenai kaum perempuan Betawi. Representasi tersebut ada yang bersifat mengokohkan citra (image) tertentu mengenai kaum perempuan Betawi, misalnya sebagai perempuan yang taat pada suami, dan perempuan yang lemah dan sebagainya, ada pula yang berusaha menciptakan sebuah citra baru bagi identitas Betawi, misalnya citra kaum perempuan Betawi sebagai penari internasional.

\section{Pembahasan}

\section{Budaya dan Perempuan Betawi}

Secara historis, Kemunculan etnis Betawi masih memunculkan perdebatan tentang proses awal pembentukan etnis Betawi tersebut. Banyak pakar yang cenderung memulai garis awal sejarah Betawi pada era penaklukan Sunda Kelapa oleh Fatahillah pada tahun 1527 dan memberikan nama baru, yaitu "Jayakarta". ${ }^{23}$ Sedangkan menurut Lance Castle dalam buku Profil Etnik Jakarta bahwa penduduk asli Jakarta berasal dari hasil pencampuran etnis terutama berasal dari kaum budak. Pendapat ini menjadi kontroversi karena kaum Betawi menolak atas pernyataan yang berasal dari kaum Budak. ${ }^{24}$

\footnotetext{
${ }^{19}$ Stuart Hall, Cultural Identity and Diaspora....., h. 51.

${ }^{20}$ Kathryn Woodward (ed.), Identity And Difference, (London:Sage publications Ltd,1997), h. 21.

${ }^{21}$ Kathryn Woodward (ed.) Identity And Difference....., h. 12.

${ }^{22}$ Stuart Hall, Cultural Identity and Diaspora....., h. 53.

${ }^{23}$ Soekanto, Dari Djajakarta ke Djakarta, (Jakarta: penerbit Soeroengan, 1954), h. 60.

${ }^{24}$ Lance Castles, Profil etnik Jakarta, (Jakarta: Masup Jakarta, 2007), h. xxiii.
} 
Dari proses asimilasi tersebut, Betawi memiliki kesamaan dalam hal adat istiadat yang berasal dari akulturasi budaya. Seperti etnis Betawi yang sangat kental dengan ke-Islamannya yang berada di kelompok tengah seperti daerah Senen maupun yang kental dengan tradisi Cina. Pada abad ke-19, perkembangan dakwah Islam semakin meningkat dengan munculnya sejumlah ulama dan habaib terkemuka. Hamka juga menemukan bukti tentang kuatnya orang Betawi beragama Islam. Selama 350 tahun dijajah Belanda, Hamka jarang mendengar anak Betawi masuk kristen, meskipun orang Betawi hidup dalam kemiskinan dan kekurangan ilmu pengetahuan. Orang Betawi masuk agama kristen adalah aib bagi mereka. Hal tersebut merupakan penolakan terhadap teori bahwa kemiskinan mudah menjadi kafir. ${ }^{25}$

Selain itu, akulturasi budaya juga memberikan dampak terhadap kaum perempuan dalam beraktifitas sehari-hari. Sehingga gerak gerik kaum perempuan terbatas karena adanya pergulatan-pergulatan yang mereka lakukan dalam mengakomodasi nilai-nilai tradisi dan modernisasi dalam kontruksi identitas Betawi. Seperti dalam penelitian Elfira yang mengatakan bahwa perempuan Betawi sering dikatakan kolot atau ketinggalan jaman yang menjadi stereotipe perempuan Betawi. ${ }^{26}$ Sehingga secara tidak langsung kaum perempuan Betawi termarjinalisasi oleh wacana yang berkembang yang menjadikan kaum perepuan Betawi sulit untuk bersaing diranah publik. Namun, stereotipe negatif kaum perempuan Betawi tersebut bertentangan dengan realitas keseharian Betawi yang mereka jalani. Banyak hal yang telah dilakukan oleh kaum perempuan Betawi dalam memberdayakan kaum perempuan yang tidak hanya di ranah domestik.

Terdapat beberapa hal yang menjadikan masyarakat Betawi menggunakan sistem Patriaki menurut Elfira dalam penelitiannya , yaitu:

1. Terdapat pengaruh budaya Arab, Cina dan Barat yang memiliki sistim kekerabatan, keluarga ataupun organisasi sosial yang patriaki,

2. Terdapat sistem keturunan yang patrilineal dan,

3. Terdapat sistem tempat tinggal yang patriokal. ${ }^{27}$

Sistem-sistem tersebut masih digunakan oleh masyarakat Betawi yang menjadikan kaum perempuan Betawi tersubordinasi oleh dominasi kaum lelaki. Peranan kaum perempuan pun lebih diarahkan pada ranah domestik

\footnotetext{
${ }^{25}$ Ridwan Saidi, Orang Betawi dan Modernisasi Jakarta, 1994, h. 210.

${ }^{26}$ Mirna Elfira, Aktifitas Kaum Perempuan Betawi....., h. 36.

${ }^{27}$ Mirna Elfira, Aktifitas Kaum Perempuan Betawi...., h. 38.
} 
dibandingkan ranah publik. Seperti halnya pada karakter Juleha yang menuruti perintah suami dan taat pada suami dalam hal mengizinkan suami menikah lagi tanpa melihat perasaan dirinya yang tersakiti oleh kekuasaan kaum patriaki.

Walaupun demikian, kaum Betawi dapat memberikan kontribusi terhadap masyarakat dan keluarga seperti halnya yang dilakukan Edah untuk menjadi penari tradisional yang terkenal. Apa yang telah dilakukan Edah merupakan bentuk kontribusi Edah dalam merekontruksi identitas Betawi. Hal tersebut membuktikan bahwa kaum perempuan Betawi dapat berkiprah di ranah publik dan domestik.

\section{Representasi Kekerasan Simbolik Terhadap Perempuan Betawi dalam Novel Kronik Betawi}

Banyaknya ketimpangan peran antara kaum perempuan dan kaum lakilaki dalam kehidupan sehari-hari secara tidak langsung telah menjadi tekanan dan menimbulkan kekerasan simbolik. Kekerasan simbolik yang terjadi di dalam masyarakat merupakan sebuah ketimpangan relasi kekuasaan dan hegemonik antara superior dan inferior. Hal tersebut disebabkan beberapa perbedaan dari segi moral, ras, etnis dan agama maupun jenis kelamin dan usia. Tiap tindak kekerasan pada dasarnya mengandaikan hubungan dan atau komunikasi yang sewenang-wenang di antara dua pihak. Dalam hal kekerasan simbolik hubungan tersebut berkaitan dengan pencitraan pihak lain yang bias, monopoli makna, dan pemaksaan makna entah secara tekstual, visual, dan warna.

Menurut Haryatmoko (2010), terdapat perbedaan antara laki-laki dan perempuan yang telah dirumuskan secara positif dalam organisasi masyarakat. Seperti halnya bentuk tubuh laki-laki yang menentukan aturan main dalam kebanyakan cabang olahraga, siklus kehidupan laki-laki yang menentukan akan keberhasilan profesional, kehadiran laki-laki yang menentukan keutuhan suatu keluarga begitupun agresivitas dan dominasinya yang dapat mendefinisikan apa yang disebut sejarah. Semua ciri-ciri tersebut tidak tertutup bagi perempuan dalam melakukan dan mencapai keberhasilan yang sama dengan laki-laki, namun tujuan-tujuannya didasarkan pada kepentingan dan nilai-nilai lelaki. Di sinilah ketidakadilan yang terletak pada kesan seakan-akan memberi kesempatan yang sama pada perempuan, namun, perempuan tetap berada dalam posisi yang tidak diuntungkan. ${ }^{28} \mathrm{Hal}$ tersebut berkaitan dengan sistem masyarakat yang

\footnotetext{
${ }^{28}$ Haryatmoko, Habitus dan Kapital dalam Strategi Kekuasaan: Teori Strukturasi Pierre Bourdieu dengan Orientasi Budaya....., h. 14.
} 
secara sistematis lebih menguntungkan kepada laki-laki seperti tentang moral, kerja, kepantasan, jasa. ${ }^{29}$ Berikut ini contoh-contoh kekerasan simbolik masyarakat terhadap perempuan Betawi dalam kehidupan sehari-hari dalam novel Kronik Betawi:

\section{Generasi Pertama: Juleha}

Juleha adalah seorang istri dari Jiih yang dipoligami oleh suaminya tanpa sepengetahuan istrinya. Poligami tersebut terjadi karena Juleha belum memberikan keturunan anak untuk suaminya. Sebenarnya Juleha tidak mandul, hanya saja Tuhan belum memberikannya kesempatan untuk memberikan keturunan kepada Juleha. Akhirnya suami Juleha meminta izin kepada Juleha untuk berpoligami secara sah dengan istri keduanya. Permasalahan tersebut membuat hati Juleha diuji, dengan kesabaran untuk dipoligami. Meskipun hal tersebut membuat hati Juleha sakit karena suaminya berpoligami. Juleha teringat dengan perkataan emaknya (ibu) sebelum meninggal bahwa tugas utama perempuan dalam berkeluarga adalah menjaga suaminya, taat pada suami. Hal tersebut sesuai dengan ajaran Islam yang mengharuskan istri taat pada suami. Perkataan emaknya Juleha yang membuat Juleha merelakan suaminya menikah lagi, seperti kutipan dibawah ini:

Perempuan itu hamil.

Minggu depan mereka akan nujubulanin. Padahal ijab kabul baru enam bulan lau. Ah, aku tak bisa apa? Aku tahu apa? Pagi ini Bang Jiih balik dari rumah keduanya (aku lebih suka menyebut perempuan itu 'rumah kedua' daripada 'istri kedua') dan menawarkan berita yang dia anggap gembira itu. ${ }^{30}$

Demikian Bang Jiih pertama kali mengenalkan aku dengan janda itu. Aku tak pernah bertanya-tanya lagi. Hingga dua bulan kemudian dia meminta ijin menikah lagi, sebab ingin punya anak keturunan, dan sudah lama ia menunggu dariku namun tak juga berisi. Dan ia menggunakan kisah Nabi Ibrahim yang kemudian menikah lagi dengan Sarah, lantas memberinya keturunan.

Janda itu datang, Bang Jiih memperkenalkannya baik-baik padaku. Usianya jauh dibawahku. Sebutlah aku pencemburu, atau pendendam,

${ }^{29}$ W Kymlicka, Les theories de la justice, (Paris: La Decouverte, 1999), h. 261.

${ }^{30}$ Ratih Kumala, Kronik Betawi....., h. 121-122. 
tapi aku tak akan menyebutnya namanya sekalipun. Tidak juga padamu! Tidak sekarang, tidak nanti.

“Jangan bingung, aye ngijinin kok!”Aku melepas mukenah, melipatnya dan menaruhnya di sajadah. Lalu melipat sajadah itu dan beranjak dari ruangan, meninggalkan si Bakal Manten di ruang itu ${ }^{31}$.

\section{Generasi Kedua: Edah}

Edah merupakan anak dari pasangan Jarkasih dan Enden. Sejak kecil Edah menyukai Tari, namun kesukaannya tersebut tidak disetujui oleh emaknya. Emaknya Edah tidak suka anaknya menari. Enden tidak keberatan jika melihat orang lain menari, namun Enden tidak suka melihatnya anaknya menari. Hal tersebut dikarenakan Enden tidak ingin mendengar gunjingan orang-orang di sekitarnya yang bergunjing tentang anaknya sebagai seorang penari yang merupakan stereotip (pelabelan negatif) masyarakat terhadap penari wanita. Enden menangkap pesan dari gunjingan tersebut bahwa seorang penari dapat dikatakan sebagai perempuan penghibur yang dapat dicolak colek dan dibeli. Persoalan itupun terjadi saat Edah menjadi korban penipuan yang katanya akan menari di Jepang, namun Edah menjadi korban perdagangan perempuan. Edah berusaha meyakinkan emaknya untuk mengizinkannya menari tidak berhenti begitu saja. Edah ingin menunjukkan kepada emaknya bahwa menjadi penari bukanlah perbuatan buruk. Dari sinilah Edah memiliki sifat pantang menyerah untuk mencapai cita-citanya menjadi penari. Hal ini tampak pada kutipan berikut ini:

"Edah bilang, dia masih punya cita-cita. Belom mau pacaran kalau citacitanya belom kesampean.” Duh saye jadi tambah pusing. Waktu ditanya cita-citanye ape, die juga ogah bilang. Sepupu Edah, Enoh, yang sepantaran ame die aje sekarang udah punya buntut dua orang. Nah ini...pacar aje kagak ada. Saye khawatir, orang-orang sekitar mandang Edah enggak laku karena dituduh jualan sambil ngibing. Naudzubilah.... ${ }^{32}$

...Tapi saye dapat info tambahan, cita-cita macam apa yang dipengenin Edah. Dia masih pengen pergi nari ke luar negeri.

Bini saye nangis-nangis, "Ya ampun Dah... lu kagak ngarti perasaan Enyak. Pegimane kalo lu dijual jadi pelacur? Orang kemaen aje lu udah

\footnotetext{
${ }^{31}$ Ratih Kumala, Kronik Betawi..., h. 123-133.

${ }^{32}$ Ratih Kumala, Kronik Betawi...., h. 234.
} 
ditipu kaya begitu. Duit udah melayang, untung elu selamet." Air mata bini saye meleleh di pipi, banjir mukanya.

Edah mengkeret. Nunduk terus kaya kura-kura ngumpet. Tapi tetep aje die enggak mau mundur dari cita-citanye. Ampun deh, punya anak sebiji aje kerasnye minta ampun. ${ }^{33}$

Dari uraian tersebut, terdapat beberapa kasus kekerasan simbolik yang direpresentasikan dalam novel Kronik Betawi, seperti Juleha yang belum memberikan keturunan anak untuk suaminya, sehingga Juleha harus merelakan suaminya berpoligami. Poligami merupakan persoalan yang membuat kaum perempuan mengalami kekerasan simbolik yang tidak terlihat, meskipun sang perempuan tersakiti oleh perilaku laki-laki, dimana harus merelakan suaminya untuk menikahi perempuan lain. Bagi kaum perempuan Betawi hal tersebut tak dapat ditolak karena mereka harus taat pada suami sebagaimana yang diajarkan oleh orang tuanya yang mengharuskan tetap berpegang pada agama dan adat istiadat. Hal ini membuktikan kuatnya masyarakat Betawi dalam memegang ajaran Islam. Hamka juga menemukan bukti tentang kuatnya orang Betawi beragama Islam, yaitu selama 350 tahun dijajah Belanda, Hamka jarang mendengar anak Betawi masuk Kristen, meskipun orang Betawi hidup dalam kemiskinan dan kekurangan ilmu pengetahuan. Orang Betawi masuk agama Kristen adalah aib bagi mereka. Hal tersebut merupakan penolakan terhadap teori bahwa kemiskinan mudah menjadi kafir. ${ }^{34}$ Hal tersebut memperkuat bahwa Islam dan Betawi merupakan hal yang tak dapat dipisahkan dan menjadi identitas mereka sebagai kelompok etnik. Tak dapat dipungkiri etnis Betawi memiliki ketaatan yang fanatik terhadap ajaran Islam

Ketidakadilan peran antara laki-laki dan perempuan tersebut secara tidak langsung merupakan kekerasan simbolik yang tidak kalah berbahaya dari kekerasan fisik yang bersifat paternalistik yang dapat merugikan posisi perempuan. Selain itu, sistim paternalistik tersebut masih digunakan oleh masyarakat Betawi yang memberikan peran perempuan menjadi tersubordinasi dan termarginalisasi oleh dominasi kaum lelaki. Sehingga peran perempuan lebih diarahkan pada ranah domestik seperti rumah, sumur, dapur, dan atau ranah yang dianggap kurang penting atau subordinat dibandingkan peran lakilaki yang ke ranah publik.

\footnotetext{
${ }^{33}$ Ratih Kumala, Kronik Betawi...., h. 235.

${ }^{34}$ Ridwan Saidi, Orang Betawi dan Modernisasi, (Jakarta: LSIP, 1994), h. 210.
} 
Selain itu, penari dalam masyarakat Betawi identik dengan wanita penghibur, dimana mereka menari dan dikelilingi oleh para lelaki. Hal tersebut yang memunculkan stereotip negatif terhadap profesi penari. Sebagaimana yang direpresentasikan dalam novel tersebut bahwa masyarakat masih memandang sebelah mata (negatif) atas profesi sebagai penari. Hal tersebut secara tidak langsung memberikan kekerasan simbolik terhadap Edah dan ibunya yang mendapatkan gunjingan dari masyarakat atas profesi anaknya sebagai penari. Padahal, profesi sebagai penari merupakan pekerja seni yang melestarikan kebudayaan.

Namun, kaum perempuan Betawi juga dapat memberikan kontribusi untuk keluarga dan masyarakat seperti halnya yang dilakukan oleh Edah yang mempunyai cita-cita menjadi penari internasional. Dengan pantang menyerah Edah telah meyakinkan kedua orang tuanya terutama emaknya, Edah berhasil menjadi penari internasional. Dengan kasus Edah tersebut, merupakan bukti keterlibatan perempuan dalam merekonstruksi identitas Betawi bahwa menjadi penari tradisional perempuan bukan merupakan profesi yang negatif sebagaimana yang digunjingkan oleh masyakarat Betawi. Namun, hal tersebut tidak dapat bertahan tetap karena hak dan kewajiban perempuan masih tertinggal dibelakang dibandingkan kaum laki-laki.

\section{Simpulan}

Berdasarkan analisis di atas dapat disimpulkan bahwa nilai-nilai budaya dan religi yang kuat dalam masyarakat Betawi memberikan pengaruh dalam menentukan aktivitas dan posisi kaum perempuan Betawi dan juga menjadi ideologi bagi kaum perempuan Betawi. Hal tersebut memberikan dampak pada perilaku dan perlakuan sosial seperti termarginalisasi, tersubordinasi, stereotip dan kekerasan terhadap perempuan yang secara tidak langsung merupakan bentuk kekerasan simbolik. Sebagaimana yang direpresentasikan dalam novel Kronik Betawi karya Ratih Kumala, bahwa kaum perempuan tidak dapat besifat dinamis melakukan aktivitas karena harus melihat kembali nilai-nilai tradisional Betawi dan religi yang cenderung menganut sistim patriarki sebagaimana yang diperankan oleh Juleha. Hal tersebut sangat berbeda dengan kamu lelaki yang sangat leluasa dan dinamis dalam melakukan aktivitas dan mengakomodasi nilai-nilai tradisi dan modernisasi dalam kehidupannya. Namun, kaum perempuan juga tidak ketinggalan dalam memberikan kontribusinya dalam proses rekontruksi identitas perempuan Betawi sebagaimana yang diperankan 
oleh Edah yang melakukan kemajuan dan sumbangsih terhadap kebudayaan dan bangsa seperti menjadi penari tradisional yang terkenal. Diperlukan suatu keberanian bagi perempuan untuk menjadi individu yang merdeka namun tetap dalam koridor nilai-nilai budaya dan religi.

\section{Daftar Pustaka}

Bourdieu, Pierre. La domination masculine. Paris: Minuit, 1998.

Butler, Judith. Gender Trouble. New York : Routledge, 1990.

Castles, Lance. Profil etnik Jakarta. Jakarta: Masup Jakarta, 2007.

Elfira, Mina. Gerak Langkah Orang Betawi: Pergulatan Identitas dan Modernisasi, Laporan Hasil Penelitian. Depok: PPKB FIB UI, 2012.

Elfira, Mirna dalam penelitian Aktifitas Kaum Perempuan Betawi Dalam

Hall, Stuart. Cultural Identity and Diaspora dalam buku Representation: Cultural Representations and Signifying Practices. London: Sage Publication Ltd, 1997.

Haryatmoko. Habitus dan Kapital Dalam Strategi Kekuasaan: Teori Strukturasi Pierre Bourdieu dengan Orientasi Budaya. Makalah ini dipresentasikan di Pasca-Sarjana Sosiologi UI, Depok, pada tanggal 26 Agustus 2010.

Krais, Beate. The Gender Relationship in Bourdieu's Sociology, dalam SubStance no. 93, 2000.

Kumala, Ratih. Kronik Betawi. Jakarta: Gramedia Pustaka Utama, 2009.

Kymlicka, W. Les theories de la justice, Paris: La Decouverte, 1999.

Masyarakat Multikultural: Antara Tradisi dan Modernisasi. Depok: UniversitasIndonesia.2012.https://multikulturalui.files.wordpress.com/2 013/05/prosiding-simg-ui-2012-jilid-2-05.pdf

Pusat Studi Wanita, Pengantar Kajian Gender, Jakarta: UIN Jakarta, 2003.

Saidi, Ridwan. Orang Betawi dan Modernisasi Jakarta. Jakarta: LSIP, 1994. . Potret Budaya Manusia Betawi. Jakarta: Perkumpulan Renaissance Indonesia, 2011.

Soekanto, Dari Djajakarta ke Djakarta, Jakarta: penerbit Soeroengan,1954. 
Nina Farlina

Swartz, David. Culture and Power: The Sociology of Pierre Bourdieu, Chicago: University of Chicago Press, 1997.

Woodward, Kathryn,ed. Identity and Difference. London: Sage publications Ltd, 1997.

\section{Artikel Online}

Kumala, Ratih, "Kronik Betawai, Sebuah Novel" diunduh dari http://ratihkumala.com/blog/kronik-betawi-sebuah-novel-3-398.php, tanggal 7 Januari 2016, pukul 11:05

http://kbbi.web.id/poligami, tanggal 7 Januari 2016, pukul: 11.03 . 